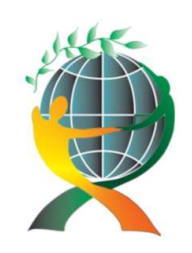

\author{
(online) = ISSN $2285-3642$ \\ ISSN-L = $2285-3642$ \\ Journal of Economic Development, Environment and People \\ Volume 8, Issue 2, 2019
}

URL: http://jedep.spiruharet.ro

e-mail: office jedep@spiruharet.ro

\title{
The Health Sector - From Desideratum to Real Reform
}

\author{
Larisa Mihoreanu \\ Business Administration Doctoral School, The Bucharest University of Economic Studies
}

\begin{abstract}
The paper states the necessity to implement a new model of management in the health sector, based on a new concept, of synergetic satisfaction having an institutional relation between patient and medical entity in its centre.

The present doctoral research finds its roots in the interdisciplinary approach linked to Health industry and market, as profitable businesses. The purpose encounters the anchor into a new concept, of synergetic satisfaction having the patient in its centre. The measurement centre resides in the societal performances' rules linked to the real needs of a health status afterthought.

Several constituents of the classical healthcare principles receive, exquisitely, shaped clarifications under the state, public and private health of public recognition.

As the principles of humanism depict the governments' obligation to guarantee their citizens fundamental rights to access health services, the international dimension of activities seed new designed health objectives. Hence the research maps a new model sustaining that the health management systems, differently recognized, can assume regular nudgers to better drive the understanding of the reality, close to financial interests and realistic resources. The implementation of the innovative and realistic reform would diminish the national burden, make people embrace the responsibility of active citizenship letting them to get involved in any process that protect the right development of a country and its citizens, far from partisan interests, only for their own future and comfort in life.
\end{abstract}

Keywords: health serviceable delivery, innovation, integrative partnering, medical business, policymodelling, reform, reputation, resilience, returned added value, synergistic management.

JEL: E29, E61, G18, H50, H53, H59,

How to cite: Mihoreanu, L. (2019). THE HEALTH SECTOR - FROM DESIDERATUM TO REAL REFORM. Journal of Economic Development, Environment and People, 8(2), 56-80. doi: http://dx.doi.org/10.26458/jedep.v8i2.627

\section{Arguments for an Integrative Health Sector System}

Before entering upon the considerations of the medicine, health and care resources, roots and development trends and into their manifold particularities and needs, a general interest may lead people to want to know more about the new excogitation related to the health sector and the medical knowledge as 


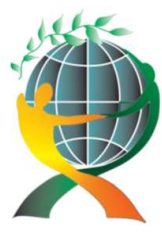

\author{
(online) $=$ ISSN $2285-3642$ \\ ISSN-L = $2285-3642$ \\ Journal of Economic Development, Environment and People \\ Volume 8, Issue 2, 2019 \\ URL: http://jedep.spiruharet.ro \\ e-mail: office jedep@spiruharet.ro
}

presented in this research entitled: "Empowering the Structural Reform in the Health Sector: An Innovative, Synergistic and Business Masterminded Approach". The coming after ideas represents an introduction into the spirit of the research and an assertion making the dreams, the objectives and purposes, more comprehensible in order to be applied. The activities run in the field of medical and health sector are considered historically, as the most originative in their becoming development and approach of the simplest habits of the humankind.

The mere free inhalation of the air of which constituents sustain the life's vitality, the proper exposure to the stimulating agency of light upon the surface are essential to the preservation of all beings' health and shouldn't undergo impaired, by the insufficiency of all the natural preservatives, by an insensible return to the natural conditions of living and by the denial of the need for a natural, authentic and respectful behaviour of Natural Law at individual level in aim for a good societal functioning.

At societal level, Health and Education are the most essential cells of the system; they are highly responsible with preserving and transmitting to the generations to come, the legacy received from ancestors and providing people with the right information allowing them not only to survive but also to evolve. Hence the topic of the present research springs from the core state-of-the-art of the Health and Care systems and develops around its connections with the other elements of Medical Science, SocioEconomics and Business fundamentals. The subject is more than essential, especially nowadays; it is on the top fields, worldwide, for the acute necessity of scientific research development and implementation and the managerial assessment and innovative changes requisite.

The evolutionary study of the Health and Care Management naturally motivates the identification and presentation of sometimes sophisticated Medical, Economic, Mathematical models, as solid contributions to the study of the so-called European Health Management. It starts with the idea that while health care represents the "large number of services rendered to individuals or communities" (WHO, 2013) by the agents of health services or professionals "for the purpose of promoting, restoring and maintaining health" (WHO, 2013), the taking up of all the goods and services designed for "prevention, promotion and rehabilitation interventions" includes the medical care (WHO, 2013).

According to the WHO global strategy (2007) as emerged in its annual reports (WHO), countries and governments affiliated to United Nations bodies are strongly recommended to integrate "the concept of Health" in their national Constitution as "a universal right" and dispose, at central and local administration levels, adequate policies and management to distinguish and discern, to accept and incorporate, in their national budget, the necessary conditions related to inhabitants' Good Health. The right to a good health is part of the principles of humanism for citizens of every country that also draws the governments' obligation to assure "their citizens' fundamental rights to food, shelter and health" (WHO, 2013). Therefore, the human right to health may be achieved differently, in different parts of the world, in different political regimes. In conformity with each country's own specific justice values, law system, ethics and morality code, the access to health is the result of a negotiation process between the one government and its citizens. The process may be sustained by different international bodies, agencies, nongovernmental organizations or various religious bodies (for example: Amnesty International, patients' associations, HIV/AIDS societies, Red, Yellow or Blue Crosses, and Save the Children and many others) acting in the health sector and representing the rights for different categories of people. This multilevel collaboration and partnerships provide the size of the international dimension of activities and actors involved, which 


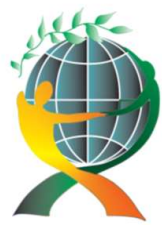

\author{
(online) $=$ ISSN $2285-3642$ \\ ISSN-L = $2285-3642$ \\ Journal of Economic Development, Environment and People \\ Volume 8, Issue 2, 2019 \\ URL: http://jedep.spiruharet.ro \\ e-mail: office jedep@spiruharet.ro
}

entitles them to seed and implement the international designed health objectives in a faster and better, simpler and cheaper, transparently and profitably manner. In this respect, the goals are oriented are to: a) sustain the global security and avoid all sorts of disaster and pandemics; b) encourage the social justice to reinforce the social value and humans' rights; c) empower the patients to create a participatory, procreative, aware and committed behaviour, for sustaining both the universal rights and the care in using public money; d) develop a new generation of partnerships to make prevention fundamental and long life integrated together with a profitable medical education. It is true that efforts scarcely touch the good finality of their suitable purposes. Often they are disproportioned and not quite visible when the wish to do well is present. Despite the fact that the great and continual effort of social energy is directed to supply and sustain the organic structure of central and local authorities, the recurrence of perturbations, instead of sustain an adaptive changing process, is frequent enough and continue to damage the development of good ideas and the implementation of decisions. Thus the administrative and managerial disturbances cause more dysfunctions within the entire system with unimaginable consequences for the future. Often, the damage is even worse when manipulative activities jeopardize the system as a whole.

Our highly dynamic society is dominated by multilevel distributive channelled structures, complicated and complex logistics of protocols, treatments and drugs, of medical devices and therapies, of producers and distributors, merchandisers and managers, medical and administrative units, central, local and collateral nongovernmental establishments, staffs, patients, agencies and authorities; their bad functioning react upon the vigour of the bona fide management and cautionary governing of health. Any languidness, inactivity, disorder, inadequate exposure affects not only the whole logistics but also each systemic component and result into economic and financial exhaustion, loss of profits, efficiency deprivation, development of turbulences. Recovery will always require even more resources (time, funds, staffs and energy). A total recovery may never be complete, if the proper timing and opportunities are disregarded or lost.

The governments may have their own vision and strategies about how to apply the health principles and achieve their related duties, but the implementation of the health principles is meant to happen openly, at different rhythms and intensities, depending on the stage of socio-economic development, political regime, culture, traditions, customs specific to each country. There are governments and authorities that reject the idea of health and care financed through taxpayer funds, while other intentions concern the increase of the state contribution at about one-fifth of GDP. Some figures remained only on the paper.

The classical European standards occur with the study of the role of central and local administrations, in parallel with the general attributions of the non-governmental charity and religious bodies, is also considered challenging, when issues are related to: a) the private insurers and their competition against the public national health insurance system (Canada), b) the public effort and costs in comparison with the individual responsibility (Australia and New Zeeland). 


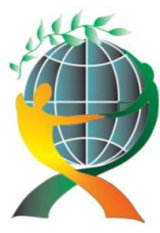

\author{
(online) $=$ ISSN $2285-3642$ \\ ISSN-L = $2285-3642$ \\ Journal of Economic Development, Environment and People \\ Volume 8, Issue 2, 2019 \\ URL: $\underline{\text { http://jedep.spiruharet.ro }}$ \\ e-mail: office jedep@spiruharet.ro
}

\title{
2. Methodological Development of the Research
}

The research, developed in English, with care for style and concern for grammar, follows all the highly scientific rigors of an enlightened structure and contains all the postulated components - from the summarization of topics to be developed to this prolepsis followed by two main parts composed of three big chapters each, split up in subchapters and outlined by summaries and ending in brief, intuitive assumptions related to the next stage of the paper. The work is designed according to the today tremendous challenges for to reshaping the reality under "sustainable development goals and rigor" (Drysdale, 2017) and follows specific highly scientific criteria to make visible the author's vision. Thus advanced researches have been identified and examined researches in interdisciplinary fields and publications closely interconnected with the doctoral topic together with the leading critical and provocative key stones while their review have been mentioned as cohesive and supportive sources of the doctoral research sustainability. The search runs over existing concepts (as established and recognized), points out local problems and political errors and gives new drives for future interpretations, political decisions in targeting allied fields, inter-operational structuring, featuring provocative preventative horizons and goals for a new social integrative contract that may turn into a synergistic global one. The doctoral research ends with conclusions followed by appendices and navigation aids: list of acronyms and abbreviations, list of tables and figures, annexes, glossary, index, and list of referential notes and bibliographic sources of documentation mentioned and ranked according to the Harvard references regulations.

Consequently, based on specific concerns like above, the doctoral research evolves in two keen directions, one more important than the other, in order to:

a) analyse of the state-of-the-art starting from punctual relevant objectives, targets and the way they relate practical results already obtained and the path to follow to bring innovation and good governance in our daily life;

b) map the road towards a less clouded but innovative model generating new types of relations and partnering, where the unique centre of support (disease, treatment, patient, clinic) is replaced by an agile, complex and synergetic, modular model related to other different systems (not items) like operational policy making, interrelated health clusters and networks, patients and caregivers. Such model can spring only through on committed acceptance and profitable outcomes with the honest purpose to benefit at the greatest possible degree of existing assets and opportunities to improve the rest of life to live. In the research's design, each of the two directions gets similar importance and care following a given structure:

The first part (Acknowledge, Inspire, and Colligate) is dedicated to the medical and socio-economic environment and fundamental concepts linked to the necessity of introducing the complex systems and creative innovation contribution in the economic patterns development of health sector. Although there is a growing and rich literature concerning the description of "linked diversity" (Barabási, Newman, and Watts, 2006) thanks to the genealogies arising in this new given shape of real situation, new results come along on the scene, by considering the moral force of actors involved in that network of systems, inside a kinetic interoperability. Disclosing the advanced introductory assumptive building blocks behind different theories covering the selected field of research, the focus remains cantered on reaching a more complex 


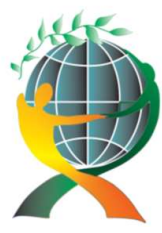

\author{
(online) $=$ ISSN $2285-3642$ \\ ISSN-L = $2285-3642$ \\ Journal of Economic Development, Environment and People \\ Volume 8, Issue 2, 2019 \\ URL: http://jedep.spiruharet.ro \\ e-mail: office jedep@spiruharet.ro
}

and better view and understanding of facts and actions, allowing the driving of a compact approach linked to the societal side, as coverage in force of both social and institutional constituents.

Following that direction, the aims of the healthcare system entail to: a) get it acknowledged, to check, monitor and improve the health status of population and the clinical outcomes of care; b) improve social justice equity in the health status of each individual; c) take care of public money and spend it wisely, by reducing encumbrances and economic burden of health and care; d) raise and pool the resources accessible to deliver health care services. The goals are to be achieved through a wide functional logistics put in movement by the useable functions of the care system: promote prevention, boost health education, nudge the health services towards the real quality; raise the life standards and expectancy; assure maternal and child health, family planning, adolescent health; hold and control the local endemic diseases; supply immunization services recognized as valuable and desired as necessary; prevent, assess and manage the common diseases and injuries. The present research will consider their limited review.

Chapter one makes up a vademecum of the empirical literature providing specific information about the fundamental concepts, the ways they operate in medicine, care and managerial business, giving a rise to a universal image of a system of systems in health care sector. The research takes on shape based on Lancaster and Stanhope definition of health care delivery system referring to the "totality of resources that a population or society distributes in the organization and delivery of health services" (2011). It also let in all personal and public services performed by individuals or institutions, for the purpose of maintaining or restoring health.

The need for healthcare services is considered, from economic, social and human points of view, a gained demand educed from the general demand for health, in order to recover or get closer to the initial health capital. Part of the universal capital of human beings, health is also part of the society physical and intellectual working capital of which requires the maintaining of a permanent allocation of resources to keep the health stock ready engaged for the regeneration and future consumption and the genetic transfer towards the next generations. Outstanding scientific researches address to the various aspects of innovation in different fields like: technology services management, quality management, operations and operational management, logistic operations, corporate behaviour, product development strategic management, marketing, economics, with "incomplete linkages in evidence across all those areas" (Hauser, Tellis and Griffin, 2006). This contends that research efforts require the carrying on to determine the contingencies between various theories in the field: Brian McKenzie (2009), Abrahamson (1991), Eveland (1990), Tomatzky Fleischer (1990), Van de Ven, Rogers (1988), Mohr (1977), to identify the lack of the concept of added value management analysis and to move the research on, in the medical and health domain. As Wolfe suggested (1994), an innovative research is developed into "three main directions": 1) diffusion of innovation, 2) organizational innovativeness, and 3) process theory, each of them being explored and explained in different ways, from classical perspectives, to new and modern dimensions. From this position, the concepts of medical, health and care landscape have been mapped, here, under the multidimensional innovation influence to broaden the horizon by transcending the boundaries of scientific and technical development of research and embracing as many sides as possible - economic, technological, social, societal and institutional including the complex dimensions of human, nature, organizational and operational factors. 


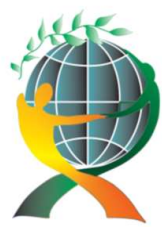

\author{
(online) $=$ ISSN $2285-3642$ \\ ISSN-L = $2285-3642$ \\ Journal of Economic Development, Environment and People \\ Volume 8, Issue 2, 2019 \\ URL: http://jedep.spiruharet.ro \\ e-mail: office jedep@spiruharet.ro
}

The second chapter provides a retrospective and prospective analysis of the needs for innovation and creativity application in the health systems outlining the specific characteristics of the health care system as an integrative supplying logistics for market potential and services administration, system of which we all are part of our entire lives. Given the highly technological and creative approach of both medical and healthcare domains - including corresponding management and policies, - innovation brings into alignment and develops a combined construction as: a) concept and manner of acting - based on mixed perception, statistical issues and real facts, and b) organizational mainspring earning competitive advantage, enhancing performance and building the future in a fulfilling and successful way. This implies a complex and agile organization of different flows of assets - people, institutional entities, resources serviceable to delivering care, to offer the satisfaction of achievement by meeting peoples health needs by different health categories and social-demographic classes. It is important to stipulate that one of the medical act approaches refers to the patient-centricity, as the main donee, having the benefactive role of a consumer of health services, as a client and not as a customer. Inside the health environment the customer could be any other medical and non-medical member or entity together with any component of the community having a related serviceable request. Customers may be less informed about health services than anything else they have the right for or they purchase.

Chapter three reflects a plain explanation on the way concepts and processes are linked to diseases' empathize and they serve both health and society as one system. The classical approach of the health care system is unique, given the universal right of health of each individual. Accepting this approach there are no doubts that the healthcare has been primely understood and developed as a non-competitive market. There are, of course, well defined restricted entries into the health care system. At present, the relations inside the health and care markets require new understandings and behavioural adjustments. A deeper attention is yielded to the natural structures of the health care system, to the new medical players and their objectives, to the business oriented operational functioning, to the interoperability with the entire society. And for this reason the thesis commits in understanding and exploring those forces that realistically drive the power of a nation in the field of educative health management, assuming the chances for better assessing the costs versus benefits with all advantages, burdens and consequences, in order to generalize an added value analysis as collateral service in the Medicare environment and performing indicator in the managerial systems and standards. It becomes obvious the necessity to embrace a new concept serviceable health delivery - rather than rendering health services as the first concept is closer to health meaning as a business competitive industry and market.

The second part (Connect, Empower and Change) appoints farther the study of creative models to be applied to the health domain as an innovative contribution. In particular, the contribution is drafted for presenting the first possibility of real-time full administrative carrying into health services actions as a competitive business on a competitive market cantered on a new concept of total active satisfaction. Therefore the research has been delineated following the basic premises regarding the interdisciplinary researches in the field of: medical sciences and pharmacology, health and care management and services, and medical business administration. The multi-dimensional-based research (Pässilä et al, 2013) has been introduced as an innovative technique of intervention - aiming to develop public health care services, in an acceptive and committed way, as a qualitative research method for interpretative user-driven innovation processes. Multivariate analyses of facts, experiences and data on the motivating factors generate 


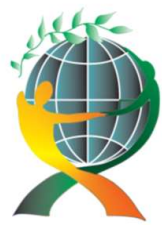

\author{
(online) $=$ ISSN $2285-3642$ \\ ISSN-L = $2285-3642$ \\ Journal of Economic Development, Environment and People \\ Volume 8, Issue 2, 2019 \\ URL: http://jedep.spiruharet.ro \\ e-mail: office jedep@spiruharet.ro
}

multidimensional perceptions of the costs/benefits realities as stated by international and national establishments along the years.

According to Rosamond Hutt (2016), the "international challenges tackling the actual multi crisis are complex" and shape the future development: hunger, malnutrition, food security, societal inclusion, employment demeanour, climate changes. They touch on all levels of the medical, health and care serviced sectors. Hence the repositioning of health concepts requires deeper understandings of the real cases and their managerial limits from the evidence-based practices.

The fourth chapter is cantered on the health fortification through innovation whiled explores the potential advantages of an innovative model of integrated management for the health sector as a whole, not only for Medicare system, in order to diminish the national burden and make people aware of the importance and benefits of the self-engagement and education, for their own future and comfort in life. The assets scarcity compels governments, establishments, staffs, and people to behave proactively and to bring into existence more added values for the society and for their own benefit. The constant of the new system is the aggregate synergy as shouted from processes' interoperability, through acceptance of the whole context, self-presence activation, returned added values' use and general commitment. A good general mental and physical condition remains fundamental not only for the future of any individual, but also for the future of nations, in their continuous struggle to handle specific interests.

Chapter five is consecrated to the embedded health rewards and Medicare management. Taking the real path of profit and mindful commitment - recommended to be total, credible, and highly motivated, the analysis prompts the medical relation with patients as the core of the embedded network driven approach of all activities as related to those creative clinical or administrative experiences to develop into new needs, opportunities, inspirational knowledge and viable practices to enhancing the hidden performing of the social capital and consolidating the innovatory services. Thus, since the very beginning, the research presents the necessity of such a demarche, outlines the major challenges at international level, and tackles the critical multi approach understandings and the new repositioning of health concepts and issues as ascertained, recognized and accepted by the European and Global bodies', in their policies and recommendations.

Towards the end of the dissertation, in chapter six, decisive guidelines are outlined for policy makers, as issued from the successful lessons learned elsewhere. The outcomes from different models and systems are here analysed within the context they were implemented in. Pillars of a robust reform in health are ramp up and a model is also proposed to better serve the strategic use of international entities' funds, to feed the innovation both into new cures and treatments and equally in punctual serviceable health and care dispensation as true competitive businesses. The skeletal frame analyse of the medical and health management and policies bounces on the fundamental pillars of the dynamics in the fields, dwell a personal approach of facts, events, and perspectives. The static approach based on individual units (treatment, patient, and clinic) is replaced with a dynamic relational perspective where the social, institutional and societal relations integrate and consolidate the added value return, based on total serviceable satisfaction and generate a mindful and committed attitude and behaviour. Hence, this approach wants to be original, dynamic and innovative, extending far inward with inscrutable accents on the need of European Union standardized views and the Romanian particularities. 


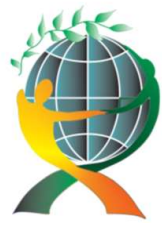

\author{
(online) $=$ ISSN $2285-3642$ \\ ISSN-L = $2285-3642$ \\ Journal of Economic Development, Environment and People \\ Volume 8, Issue 2, 2019 \\ URL: http://jedep.spiruharet.ro \\ e-mail: office jedep@spiruharet.ro
}

The last chapter is dedicated to conclusions where a revision of the presentation is followed by other detailed elements limned in the master presentation of the thesis. Important scientific elements are to be outlined for a correct assessment of this paper: the introduction of a competitive, business correlated approach of the medical and health activities that, through the palliative tasks could be traditionally considered as business administration of medicine and serviceable care delivery; innovative correlations with different sides of the management activities (medical management, administrative management, operational and risk management, time management, sanitary management, hospital management, healthcare management, palliative management, claims management, pharmaceutical management, all synergistically linked for the first time together, by integration, with innovative management, signal management, relational management and health technologies assessments management. This helps proving the switch from health delivery to serviceable medical and care delivery, underlining the returned added value incorporated by good competences, the performing and committed attitude and the highly qualitative deliverance of any activity. The fact that not an item but a relation is now the core of the relational-based net management will move the facts straightforward as it will be easier to identify and analyse pairs of assessed behaviours and data to reach the best of answers and new target to take.

The research purpose scrutinizes collateral sides as well, to emphasizing the business and profit orientation of the sector: a) looking for alternative answers, by applying complex scientific procedures in order to discover hidden truths or understandings; b) gaining new exploratory considerations, deep perceptions and understandings of the present situation; c) tracing new interdisciplinary and inter-linked sectors/domains/sciences and d) generating later associative diagnostics, prior to give examples of hypothesis' insights. The research acknowledges that Health Management, a domain of recognized authority and pedigree, classically describes the leadership and the general management of hospitals, their networks and/or health care systems and retains the international dimension and use of those terms at all levels: management of a single health institution providing medical or care services. Thus, the health systems management terminology is partially recognized and accepted whether any administration or health facility attained the medical and care specific goals, running smoothly and performing their jobs so that patients understand that they are together to accomplish common goals.

During the medical collaboration between medical staffs and patients, the first ones sustain any other societal preventive and preventative or collateral needs (reports, medical letters, treatment results and the relations between their issue and patients), and avoid any supplementary burdens or encumbrances provoked by patients' body damage and illness. Once these clarifications solved, the conditions of elaborating the research hold up beyond the time homogeneity and the scientific substance linearity of the environmental situation in medicine and healthcare around the world. Actually, economy and society are too complex to be analysed and administrated only via classical, traditional concepts. According to most references and dictionaries, the word medical represents the branches of medical science dealing with nonsurgical techniques, while medicine includes surgery. A medical corpus is formed by graduates of health schools and universities (physicians, specialist doctors, charge, specialist, staff nurses and midwives and nursery nurses), trained for different types of medical schools, looking highly devoted to their jobs, treating, preventing and alleviating the symptoms of any disease together with other non-medical administrative staffs. They are supposed to be totally engaged in their dialogue with patients, supporting their wishes for living at high standards both physically and mentally. They are also supposed to be assisted 


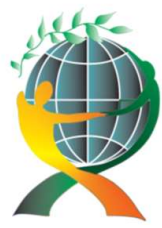

\author{
(online) $=$ ISSN $2285-3642$ \\ ISSN-L = $2285-3642$ \\ Journal of Economic Development, Environment and People \\ Volume 8, Issue 2, 2019 \\ URL: http://jedep.spiruharet.ro \\ e-mail: office jedep@spiruharet.ro
}

by the rest of the health workforce - the non-medical staffs: healthcare support workers, registrars, statisticians, and so on, to diminish the administrative burden on doctors' shoulders and liberate them so they could spend more time with the patients instead of hampering them with administrative burdens.

The healthcare is mainly focused on keeping the mental and physical health, between the touchstones, standards or norms of the good conditions, and treating the people who are sick and their illnesses. Usually this happens by providing complete therapeutic schemes or treatment algorithms under wide examination and monitoring services, by highly trained medical professionals. As several constituents, exquisitely, require some shaped clarifications, the present research is directed to explore public health and care delivery, comprising the state of being healthy, the concept of health, the public and the private health of public recognition. General references are directed to social insurances for the ill and injured people including the two kinds of schemes for public and private health and care delivery, while the Medicare activities are part of the national public health system, financed by taxation.

The realistic added value (less returned than needed) of the medical and healthcare activities is rather ambiguous, coming from subjective interpretations, rather than eco-lighthouse certification of integrated, permanently assessed activities. Since the research construction has considered data from various official and internationally recognized databases where countries like Romania are, often, let aside or incompletely represented with proper data in long series, the paper reached some implications and its own limitations. Missing or reported incorrectly data encumbrance the dynamic cross-sectional analysis and their full assessment. The stipulation, in different documents of unlike versions of the same indicators, emerged in limited, non-representative decisions of relevant respects. The technique is usually used in gerrymandering management with the obvious purpose to manipulate assets and people and speculate personal advantages as a political position. Therefore, active readings around the topic, taking notes and mapping out where personal arguments settle, make up outstanding steps taken along the research.

The theoretical part of the research went on with perusal of the most outstanding published works links to the topic, through reliable data sources such as (World Bank, United Nations, OECD, EUROSTAT, national statistical offices), archives of public libraries and print and electronic versions of published academic papers quoted ISI Web of Science and Web of Knowledge, allowing also an enlargement of the debate and designing the personal contribution to give for the thesis.

As the research corroborates results of different international studies, the novelty consists in the way the health service is analysed: as an aggregate of national security and safety importance, and a facilitator of learning from the multidimensional experiences to bridge the gaps between the patients, medical staffs' and decision makers' perspectives, for a better service delivery, cost reductions, and collateral benefit effects.

Analysts like Fletcher and Brannigan-Smith mentioned (2004), that the novelty and the success of any research are reached once "new tools are identified and used" in rationalization and social desirability bias to "reintegrate the added values, as significant contributions" (Monkerud and Ytterhus, 2013). In a period of time when all governments put a hard political pressure on their citizens' health outlining the national financial burden, the public expectations shape new calls for implementing a proactive behaviour in creating a real and integrated added value system to satisfy people's necessities, to spend less, and impose governments to do a better job for citizens, society and their nation. 


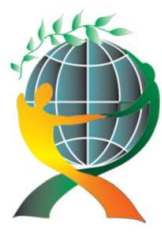

\author{
(online) $=$ ISSN $2285-3642$ \\ ISSN-L = $2285-3642$ \\ Journal of Economic Development, Environment and People \\ Volume 8, Issue 2, 2019 \\ URL: http://jedep.spiruharet.ro \\ e-mail: office jedep@spiruharet.ro
}

The health is more complex than people and decision makers could imagine. Similar to a galaxy, the system responsible with maintaining health is composed by central and local authorities and decision makers' entities, medical and non-medical staff, non-governmental associative collectives, religious communities, former, actual and potential patients, each of them highly interconnected and part of a bigger entity. From this perspective, the patient is the last on the list. Establishments and other entities have not only their own dynamics and laws, movement and rhythm, interests and motivations, but are linked and influenced by the general movement and rhythm too. The performing tracks brought out from the huge network-driven considerations remain a good lesson to take if translated in sustainable recommendations and policies.

The time to ignore the complexity of the societal postulates gone for good; now it is the high time to alter the classical approach with a neural driven coming near high satisfaction services dressed in innovative dispenses. Therefore, the current thinking, based on pioneering examples and work, shed light onto acceptance committed to opportunity recognition, performance identification and decision making that could become referential, if embedded.

The strategic use of European funds gives a new hint for integrating the concept of serviceable innovation into new trusted cures and treatments, health policies flexibility, healthcare services trust delivery, in medicines and protocols regulatory principles used and implemented as agile entrepreneurial, profitable business leading all actors involved. Given the high technological and creative approach of both medical and healthcare domains, including corresponding policies and management, innovation focalizes and develops a combined construction - concept and manner of acting - based on mingled perception, statistical issues and real facts, as an organizational mainspring for gaining competitive advantage, enhancing performance and building the future in a fulfilling and successful way. From the large variety of research typologies, the followings were retained and used:

- Ex post facto research for more descriptive than analytical situations as they exist today. Under the impossibility to take over the variables evolution because of interruptions of data series, an accurate presentation of them is used to present a picture as a whole.

- Outline the fundamental facts to sustain the lack of applicative innovation. The present paper bounces on general formulations of a health management theory looking for new innovative shoots for immediate solutions of acute problems that society is facing. The studies referring to organizational and human behaviour carry out the fundamentals affecting the social, economic or political nature of facts aiming to discover solutions of practical problems.

- For the good of the paper both quantitative and qualitative analyses are considered to outline organizational reasons of decision-making and management, to understand policies motivations and results obtained, to identify limits and constraints, to explain the reasons of under development. Thus, various factors may be expressed, analysed and put before (Young, 1960) being stated; however, the application of qualitative research remains relatively difficult.

- The conceptual approach of the research is related to international dates, acts and facts, based both on classical and modern scientific theories and results, as start points of new conjoint analysis and interpretations.

- Some assumptions and judgments spring from observation, documentation and field research, at their source. The experimental design, of which the personal thinking is developed, has been provided by 


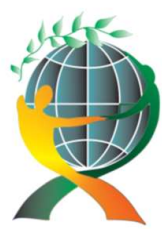

\author{
(online) $=$ ISSN $2285-3642$ \\ ISSN-L = $2285-3642$ \\ Journal of Economic Development, Environment and People \\ Volume 8, Issue 2, 2019 \\ URL: $\underline{\text { http://jedep.spiruharet.ro }}$ \\ e-mail: office jedep@spiruharet.ro
}

working hypothesis or judged from desired information. All other variations of research are approaches based on the same initial purpose, outlining facts as a one-time research (vertical research), touching several levels or dimensions.

- The study departs into the causes of things being exploratory prior to be formalized. Sometimes, the historical approach is used when the medicine and health care evolution is described, based on historical sources and documents, denotatively mentioned.

The doctoral thesis is also conclusion and outcomes-oriented as some proposals and solutions are presented to improve the health and care services activities as an integrated system, once the main issue identified enquiries redesigned and coming conclusions conceptualized. The efforts made to emphasize appropriately the health situation and the needs to realistic reforms are more interferential than qualitative or quantitative as facts express characteristics and relationships in different administrative domains. Pragmatic solutions, already in force, are given by the vivid examples of European Reference Networks (ERH) - as interconnecting operational systems and by the health technology assessment (HTA) as a highly technical multidisciplinary tool of operational management.

\title{
3. Reverberation on How to increase locally the benefit induced by ERN
}

The new ERN concept is to build an embedded applied science, issued from all the old European existing networks and nongovernmental bodies working in this field, in a domain generally classified under the classical typology of diseases (cancer, kidney, endocrinological diseases, etc.) to cover the full spectrum of congenital and acquired conditions and provide modern treatments to as much as possible patients and treat those not identified as sick people yet.

The ERNs has started to contribute at boosting the general economy of rare diseases, use more efficiently the health resources, contribute to the national knowledge increment and regional solidarity to cure all patients in need, under similar conditions of approach and treatment. Sharing the knowledge on different diseases in a framed way will enable the use of the most modern medical, care, and managerial platforms to unable the skills and treatments development - eHealth and telemedicine - will give a practical effect of experimental and working visits consequences, will transcend the training activities to its more pragmatic side, increasing the medical dialogue, give more accuracy to communication and dissemination and reduce the diagnosis timing under less tests. Each European state member could get involved bringing knowledge, specialists, resources and treatment cases, if initial conditions are respected.

The ERN keeps running since March 2017 and already have been described as identified about 8000 syndromes occurring at a rate of 1 person in 2000 potential patients.

The new networks are decided to work in the following directions: kidney diseases, bone disorders, craniofacial anomalies and ENT disorders, epilepsies, adult cancers (solid tumours), haematological diseases, urogenital diseases and conditions, neuromuscular diseases, eye diseases, genetic tumour risk syndromes, diseases of the heart, inherited and congenital anomalies, congenital malformations and rare intellectual disability, respiratory diseases, paediatric cancer (hemato-oncology), hepatic diseases, connective tissue and musculoskeletal diseases, immunodeficiency, auto inflammatory and autoimmune diseases, neurological diseases, skin disorders, transplantation in children, hereditary metabolic disorders, multisystem vascular diseases. As for the future treatments - the myoblast grafts consists of the injection 


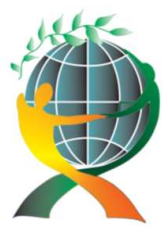

\author{
(online) $=$ ISSN $2285-3642$ \\ ISSN-L = $2285-3642$ \\ Journal of Economic Development, Environment and People \\ Volume 8, Issue 2, 2019 \\ URL: http://jedep.spiruharet.ro \\ e-mail: office jedep@spiruharet.ro
}

of muscle cells in the undifferentiated state, in order to settle such muscles. Various gene therapy is to inject a portion of the DNA (DYS gene) thereby allowing the manufacture of the missing protein in following colonization affected muscle.

This technique can also correct mutated DNA of the patient. To bring the change in the rare diseases home, focus should also channel to:

- industry-wide shift towards rare diseases as potential scientifically tractable and commercially attractions,

- knowledge and data gaps step-down between regulatory assessing risks process and yielding the innovative drugs market authorization,

- development of the reimbursement process within a clinical effectiveness reported at cost-efficiency in national health and social care systems,

- sharing the science, treatment and care knowledge among all countries concerned as none is able to find general solutions in the rare and complex diseases chapter.

In all countries, rare diseases are and should be considered a public health priority in any country. Many of the rare diseases still remained undiagnosed or are too lately diagnosed because of very few knowledges of them, because of very few doctors acknowledged in these researches, because of the reduced number of specialists in genetics and the absence of specialized genetic diagnostic centres.

There is also insufficient information on an adequate scoreboard for both specialists and patients allowing for correct diagnosis and application of existing good practices and treatments, for adequate rehabilitation and societal integration. The few working networks of specialized centres are not affiliated to remarkable regional/international networks of specialized medical centres in force for detection, diagnose and track patients with rare diseases. Laboratories testing to confirm genetic diagnosis performed mainly in big cities, under very high costs, not always recognized and reimbursed by the smaller states where there are no protocols, procedures, guides to good practice in use and where the patients' identification is hardly and improperly monitored. Such situations come along, in blind, with confused statistical studies on the frequency of rare diseases. In countries like Romania there is a high need for a sustainable activity for early diagnosis and access to treatment, inside a strong network of specialized social services of which development be sustained by permanent monitoring, statistical data recording for a better detection of rare diseases and genetic counselling of both patients and their relatives.

In Romania, the non-governmental efforts of different associations involved in the rare diseases, succeeded to set up the National Council for Rare Diseases (in 2013) - by affiliating Romanian Society of Medical Genetics, about 30 organizations and groups of patients linked by those diseases, a large group of specialists and only few representatives of the central administration. The purpose laid the foundations of a Rare Disease Plan to implement a coherently mechanism to eliminate the scientific isolation and develop suitable treatments. Notwithstanding, the results achieved are discontinuous, uncorrelated with the daily efforts made by authorities, specialists, patients and their families, for a more consistent central policy in the field. Some improvements are already visible. Nevertheless the implemented results are still in suffering as the visibility is searched ore for the political reasons than the patients cure and satisfaction. Thus, the National Agency for Medicine and Medical Devices (ANMDM) is increasingly collaborating in the field of regulation with European Medicine Authority to set, and tune the national activities with the 


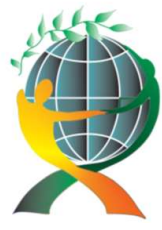

\author{
(online) $=$ ISSN $2285-3642$ \\ ISSN-L = $2285-3642$ \\ Journal of Economic Development, Environment and People \\ Volume 8, Issue 2, 2019 \\ URL: http://jedep.spiruharet.ro \\ e-mail: office jedep@spiruharet.ro
}

European recommendations within the medicines regulatory network, with those activities oriented towards the human medicines and medical devices. It handles applications for all medicines that are authorized nationally, conducts post-marketing surveillance and enforcement in their territories, authorizes clinical trials, provides national scientific advice, supports innovation and conducts inspections. ANMDM also coordinates the pricing policy and reimbursement for human medicines- outside EMA's role. The President of ANMDM is, de facto, part of Heads of Medicines Agencies (HMA). It should get acknowledged about EMA's role and apply it according to the European Union recommendations in the following directions:

- coordinate the scientific evaluation of those medicines that are authorized through the centralized procedure (the majority of the new ones),

- support for innovative products (including the provision of scientific advice and qualification of biomarkers),

- design orphan status or classification as Minor Use Minor Species (MUMS)/limited market, agreement to paediatric investigation plans (PIPSs),

- coordinate EU wide work, policies, recommendations on safety monitoring of medicines.

Under the strategic priority areas- four key themes - regarding the human health, veterinary medicines, operation of the network and global regulatory environment, authorities and Society - are called to understand better the fundamentals and new borders of modern medicine evolution (diseases, policies, technologies and treatments), to gather accurate and more reliable information about the new scientific basis of new diseases, to define them and to harmonize the knowledge for of the old ones.

The new major public health threats are linked to the eco-demographic changes - aging, migration, increasing costs of living, relative pauperization, complex development of the new medicines, antimicrobial resistance, new/old infectious diseases, and genetic diseases and dementia poly-pharmacy and co morbidity. Therefore, the 2015 European Strategy in the field of reinforcing innovative cooperation between science, regulatory agencies, decision makers and academia relies on: an increased integration of the mixed knowledge for its faster implementation and entrepreneurial bounce in their development through the European medicines regulatory network that facilitates the translation of their scientific discoveries into patient- focus treatments. Since then, achievements are more visible in technologies than in operational regulations.

The European Medicines Regulatory Network (EMRN) should be accepted and used as a unique model in the global regulatory environment, a network of all national medicines regulatory authorities for both human and veterinary medicines from Member States in the EU and EEA, united in the Heads of Medicines Agencies (HMA), and the European Medicine Authority (EMA). Serving a population of over 500 million, it has within the world's 3rd largest population after China and India. According to EMRN vision and mission, patients and animals have access in Europe to medicines that are safe, effective and of good quality. Patients, healthcare professionals and citizens are provided with adequate information about medicines. To be relevant and cover the future's needs, to accomplish efficiently and transparently its purposes, EMRN inquires a wider cooperation with other regulators in order to respond to the increasing globalization of the pharmaceutical industry calls for: concept "One Health" or "Personalized Medicine" a getting together approach based on human and veterinary medicines regulations; innovation, new technologies, 


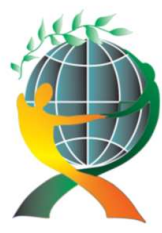

\author{
(online) $=$ ISSN $2285-3642$ \\ ISSN-L = $2285-3642$ \\ Journal of Economic Development, Environment and People \\ Volume 8, Issue 2, 2019 \\ URL: $\underline{\text { http://jedep.spiruharet.ro }}$ \\ e-mail: office jedep@spiruharet.ro
}

personalized medicine covering unmet needs; monitoring benefit-risk balance of medicines throughout their life cycle, based on real world data especially in case of earlier access; maintain continuous access to existing medicine and build robust supply chains; supporting the development of generics and biosimilars (biologic medical product almost identical copies of original products manufactured by different companies) non-prescription medicines.

Acting according to the principle of doing, checking, acting should not be seen as a once-and-for-all actions; one may go round the cycle more than once, particularly when: starting out; developing a new process, product or service; or implementing different changes.

All the above will keep the door open to farther chances to rare diseases patients granting an easier access to health and social care services (identification of rare diseases nature and causes by studying the symptoms, medical check-up and monitoring, access at need to the appropriate drugs used in medical treatment, alternative and complementary health and social care) to patients no matter who they are or where they live.

The good network driven governance will help sharing and spreading expertise, will promote the good clinical results, will disseminate the best practices and transform them into recommended guidelines, will empower the patients, will improve knowledge, will give a new hint to basic research, will create a happier life for people ready to return to work and bring back the hope inside the society ready to embrace happier citizens.

More and more scientific studies depict higher concerns: (Murray and Lopez, $1996 \mathrm{a \& b}$,) for defining the "evidence-based health policies" (Dobrow, 2004) to strengthen the global health as a core component of the world sustainable development. Important efforts are done to:

- determine countries to adhere to the international ware data to develop comparable and solid analysis basis in all healthcare sectors,

- find the right way to guarantee a sound, effective, efficient, profitable and equitable use of society's money (from public and communities sources) for all citizens' health,

- identify decent solutions to provide full access to high quality health services and sustain the care through different programs,

- promote and sustain the role of the health preventive education together with each individual's responsibility towards their own health and healthcare,

- reduce the bureaucracy and limit the burden of governmental expenses, considering also the need for aggregated gains at societal level,

- create the possibility of the free access to any medical services, if the society understands the principles and is ready to implement such a vision and strategy.

\title{
4. The Health Technology Assessment - An Innovative Tool to Fortify the Access to Health System
}

The today healthcare concepts compound core and side of the modern science and technology more than of the managerial one. This sends the links toward the non-discriminatory access to medical act and scientific information, the highly educated specialists, innovative adequate medication, revolutionary medical devices and equipment and improved services' delivery. As the care services consume large 


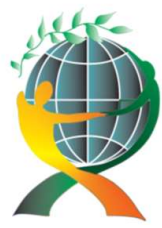

\author{
(online) $=$ ISSN $2285-3642$ \\ ISSN-L = 2285 - 3642 \\ Journal of Economic Development, Environment and People \\ Volume 8, Issue 2, 2019 \\ URL: http://jedep.spiruharet.ro \\ e-mail: office jedep@spiruharet.ro
}

amounts from public and private sources, rules, monitoring and assessment for transparent and wise spending become more than necessary, for patients and entities' benefit. So the quality of the managerial activities increases in importance while the structural aspects of the health services sustain the skills and the strategies' redesign. To a greater extent, factors are identified as influencing decisions: integrated cost benefit analyses, need for remediation templates issuing, examination of possible choice based on different choices and scenarios' architecture.

The responsiveness of a health system and the patient's preferences undergo as important parts of the governing interests. Now, the doctors' engagement is cantered on a complex approach of the patients' health and related to value and importance. It is now noticed that their high professional-moral value denoting responsibility in saving lives doesn't account when material resources are missing, when patients' number and their diseases' severity exceeds resources, when they are hold back to access innovative treatments. Important diseases are taken apart because of lack of medical education and prevention, because of watery knowledge in understanding behaviours and treatments' fundamentals. It is pointed out that the quality of health services stays under the influence and sustainment of creative innovation application, of which influence dominates the health research, the Administration's management.

The strategies of the big corporate in pharmacology and biotechnology emphasize permanent pipelines of reverse revenues to cover the investments made in drug research and development. The ferocious competition looks their common interests and partnerships are invariably applicable and potent. This approach is melding with the development of Merchant Medicine, a new a very dynamic player on the medical market, tracking the growth of retail medical care services.

To promote the good goals of the medical and healthcare activity, important rigors are appealed to be considered: a) strategic purchasing directed on quality and financial parameters, b) health technology assessment (HTA) in setting priorities, c) monitored transparency in taking decisions, d) transparency and rationale in investments, e) price reductions for Pharma produces closely linked to proof regarding the relation cost/effectiveness, f) rational use of dispensing, g) wise step-down of all disbursements (administrative, medical, nonmedical).

Under the technology and science hold, new activities, professions and decision-making processes design the socio-economic boundary, based on new-fangled principles of management, acting out in the beneficial interest of the people; not harming humans; inducing autonomous decisions in full freedom and knowledge relating to the ecosystems interactions and contributing to an equitable distribution of the benefits associated with the accessibility of intelligent home's assistance delivering also healthcare.

There are plenty of situations when the patients confront the discontinuity in treatments and therapies, given the errors in therapy protocols, health management coverage assessments and supplementary reviews. To avoid negative outcomes of such situations is necessary the direct access of prescribing/ordering providers, at upper, associative level, for the same treatment management program.

The health reform suffers damages if: the cost for a medical visit increases, less people are covered by the public insurance, the coverage value and conditions are reduced, the waiting time for essential services is disturbed, the quality of medical act is perturbed by the medical staff diminishing salaries or increasing number of working hours imposed. 


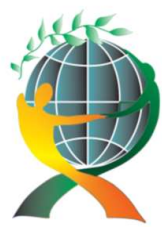

\author{
(online) $=$ ISSN $2285-3642$ \\ ISSN-L = $2285-3642$ \\ Journal of Economic Development, Environment and People \\ Volume 8, Issue 2, 2019 \\ URL: http://jedep.spiruharet.ro \\ e-mail: office jedep@spiruharet.ro
}

A very technical and targeted field of the implementation of the scientific innovation, which is based on a day-to-day practice, newly introduced in the real life, in order to give a modern and efficient form to the regulation management in one of the many national agencies of Romania (National Agency of Medicines and Medical Devices - ANMDM). My collaboration with ANMDM represented months of observation of the dynamic behaviour of the regulation and assessment systems of medicine approvals under controlled conditions, weeks of verifications and comparisons between EMA network and their different procedures put at work, hour of discussions with the big international pharmaceutical representatives in business meeting or international conferences to decipher their objectives and interests and to identify ways to add it to the societal gain. The approach generated outstanding results seen in the structure organization and human resources adequate improvements, as subjects to rigorous formal controlling analysis.

Applied to the field of human medicines, HTA is the main used mechanism, to improve the access of patients to innovative medicines. Under the national authority with competencies in the field, the HTA may be the driving force of this process by which European recommendations could come closer to each nation citizens through reimbursing innovative treatments, making accessible to all people the most innovative results of medical scientific researches, treating better hundreds of thousands of people diagnosed with highly severe diseases: cancer, cardio-vascular diseases, rare diseases and so on. HTA is a young process in the field of scientific research, a dynamic mechanism of optimization and active implication of patients and health professionals, to support the political decision making to drive the health sector to its success. An aggregated but versatile strategy is required to build a nationwide health infrastructure allowing the data sharing between all health's players: providers, consumers, and payers, according to fundamental principles built on patients' interests, safety and security.

The health management information systems are, in fact, business information systems, providing competitive advantage based on document content, analysis within data base applications and business intelligence software's able to make technology uses a better support of the decision making to develop the medical and administrative acts also as profitable and performing businesses where all data recorded.

The current research addresses the necessity that the today HTA process be officially put under the executive lens - framework, mechanisms and actors involved, to emphasize the results already obtained and design its prioritized strategic path to obtain the maximum of benefits for both society and any patients in need. Principles and procedures of inquiry and investigation serve as centre of operations and engaging the most appropriate methodologies to look up for:

- the scoping review on the conceptual underpinnings of health activity;

- the critical analysis of health workforce data, indicators and register methodologies;

- the innovative methodologies (open innovation, business model innovation, lean start-up, social, einnovation, reverse innovation) on the experiences and motivations of the mobile health professional;

- the literature analysis and experts points of view to capture the impact on different aspects of the medical life and health sector development, the need for new specific policy instruments and the role of innovation in using the signal management impact as a major suggestion of advancement (improvement, growth and robust development).

The different perspectives employed by medical specialists and management leaders enforced the multifaceted analyse of socio-eco-medical concepts. These days, innovation's definition goes far beyond 


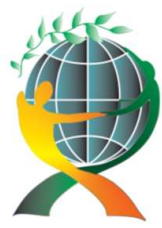

\author{
(online) $=$ ISSN $2285-3642$ \\ ISSN-L = $2285-3642$ \\ Journal of Economic Development, Environment and People \\ Volume 8, Issue 2, 2019 \\ URL: http://jedep.spiruharet.ro \\ e-mail: office jedep@spiruharet.ro
}

the definitions given a decade ago: it is not only a "tool of entrepreneurs" (OECD, 2005), used to exploit opportunities; it contributes to the development of new liaisons, opens the research boundaries, links strongly different players of the medical act, create a new generation of partnerships conducting to new discoveries put at the humankind disposal. And this is the most important area for this study. Behind the concept of innovation, exists and develops an assembly of broad, complex, sometime chaotic processes, focused on renewal. Their approaches are often described by different characteristics: nature (incremental, radical), object (product, service, process, and concepts), and dimensional level (intra, inter, open). Hence, they represent a multidimensional developments' collection, as many venues within the field of open innovation, all founded on solid theoretical findings and investigations of new trends or specific niches providing new perspectives in addressing the growing and transformative complexity and sometimes the confusing nature of the innovation concept. Nevertheless, the resistance to such changes is always present, for various, specific reasons such as: the fear of moving forward to the unknown (including the loss of profits, earnings or benefits) or the lack of tolerance in undertaking action and assuming new responsibilities, the decision makers' inability to accept the change, their arrogance and disrespect towards others' capabilities, capacities and skills to design better patterns and projects.

The inherent irreversibility of those processes claims: a) intuitive knowledge and courage, b) manipulative management dismantling, c) decision making robustness definitely based on the reality show of facts than on isolated, inadequate statistical data, d) self-confidence, self-awareness and commitment related to individuals, idiosyncratic attributes and behaviours. However, the description of a dynamic sector such as the medical one requires a heavy real-time updated lectures, a huge data base of information analysed and processed using evolution equations for large quantities of information from many sectors of activity and from far more numerous economic and business agents. Usually, stochastic models are preferred to construct the global trends.

The complex processes of economic information are tremendously dynamic, and demand large interpretation based on nonlinear dissipative models. Recall the different attractors from economic cycles can only be explained as synergetic effects by non-linear actions of consumers and producers, different production and distribution policies. Even in management, the complex models are discussed in order to support creativity and innovation by nonlinear cooperation at all levels of management and production. Merely, the experience shows that the rationality of human decision making is bounded. Human cognitive capabilities are overwhelmed by dramatic challenges and the complexity and randomness of the nonlinear systems they are forced to manage.

Challenges are more and more present in the big loss of the pharmaceuticals' market capitalization, in the "market versatility", and ever "new treatments findings" (Douglas, 2012) for more complex disorders such as: cancer, obesity, diabetes, infectious and cardiovascular diseases, mental disorders or orphan conditions, - called rare and mainly unknown to the health care professionals, - many without a cure treatment (NHS Commissioning, 2012). Under these conditions, "not easy to understand" and manage (NSH Commissioning, 2012) more consideration is absolutely essential to avoid the unimaginable consequences. While deepening the research innovation in the medical and healthcare management fields comes into being the coordinate compound and solution and it necessitates a favourable environment endorsing the take-off of news ideas and their successful implementation; it is expected it will neither destabilize nor hinder the "entrepreneurial energies" (Douglas, 2010). 


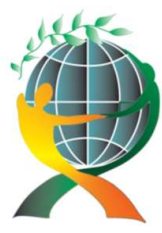

\author{
(online) $=$ ISSN $2285-3642$ \\ ISSN-L = $2285-3642$ \\ Journal of Economic Development, Environment and People \\ Volume 8, Issue 2, 2019 \\ URL: http://jedep.spiruharet.ro \\ e-mail: office jedep@spiruharet.ro
}

Today's new challenges test the medical, health and care sectors, pressure the real time adaptation for better serving patients with needs and require open policies to diminishing the society costs' burden generating an integrated proactive behaviour as a sustainable support of the real decisions. Nevertheless, this does not let the system to ignore the health care principles: cohere all medical and health care services, set into opposition with the "fees for practice" concept, defend the prepaid group practices. The spatialtemporal coordination of intra and inter flows and their relation with the stress and the speed of motivation in taking decision necessitate a particular attention.

According to this research, the identification of a synergistic model of motile small unit serving as part of a larger decision making and a policy system may strengthen the coordination activities' development and their consistency with living technical and social experiments while demonstrate that the added value bounces from multivalent aggregate coordination, vectorial flow and adhesion based on speed of motive and power of implementation.

The international beneficial experiences show the good results from some developed countries both healthcare research and in field implementation (Australia, Scandinavia, Israel, and Canada). However, commons issues beneath the national specificity touch are, also, present, on both the developed and the emerging countries agendas: a) the social and regional inequities and the stress caused by inequalities, increased poverty polarization and defective management in the healthcare field; b) aging population issues; c) cardiovascular diseases, traumas, depression, nutrition, diabetes, obesity and related conditions; d) micronutrient deficiency conditions - iron, iodine, vitamins B, C, D, Ca, Zn, Se; e) managerial standards performances and costs' assessment, monitoring and control; f) signal management referring to absorbing and implement new business techniques and new technology, deals with the last pharmaceuticals; g) human resources for the future generation of health labour force. Those countries deal with similar ever changing needs and demanding situations too: health targets and priorities (Benisheva-Dimitrova et al., 2008): a) make out the costs, benefits and losses and profits as an analysis of effectuality; b) reform in structure and content; $c$ ) health educative promotion, population-based health approach; d) migration flow consequences; e) "switch from norms" and good standards to "performance indicators" (Kalinichenko et al., 2013).

Challenges come also from the emerging markets pointing gaps in responsible awareness, managerial and medical education and big needs of investment in their health care infrastructure and complex logistics (human, equipment, ICT, methods of implementation). Other challenges relate to both new treatments' understanding and application under specific conditions and the lack of appropriate management and public policies implementation in the field.

The course of the society is sustained by information and communication technologies (ITC) that can't be left out as a result per se. ICT represent the cornerstone of improvement and nurture the living conditions, holding the socio-economic aspects and the lifestyle adopted. This is the reason why the concept of health related to the quality of life remains a progressive indicator within the set of measures regarding the efficiency in health care. Despite the sensitive and caution recovery in specific part of the world, the main problem faced by the medicine science and care services remain the same.

The health quality management requires sound periodic assessments for added value returns and integrated satisfaction, to designate the robust prestige of a system, along the societal life cycles. Its value 


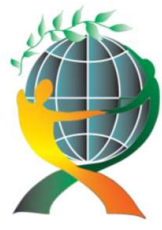

\author{
(online) $=$ ISSN $2285-3642$ \\ ISSN-L = $2285-3642$ \\ Journal of Economic Development, Environment and People \\ Volume 8, Issue 2, 2019 \\ URL: http://jedep.spiruharet.ro \\ e-mail: office jedep@spiruharet.ro
}

is higher when associated with socio-economic markers, as statements of a good life (Smith, 1999); (Currie, 2009; Cutler, Lleras-Muney and Vogl, 2012). The investments in health and the central authorities' allotments remain disparate, in countries with low and middle incomes or sensitive political development. The absolute spending increases and relies heavily on out of pocket expenses, emergency and development assistance.

According to the European Union surveys run to assess the data quality (Bergdahl et al., 2005), the dynamics of figures show that the typical and systemic problems act as the core of such a sore development almost everywhere: a) corruption, b) inadequate logistics and structures, c) volatile delocalization of both medical staff and patients who are looking for better care and services, d) increasing income inequality, e) lack of innovation. The health care expenditures remain variable, always in lowresource settings, even if is associated with the economic development and living standards. A general acceleration on the health change policy implementation could generate public health spending increase beyond the external indorsement through nongovernmental bodies' assistance. The analyses show that neither time nor economic development guarantee adequate prepaid health resources. Therefore, driving forces are required to improve the approach of health concepts prior to study the health state, the quality of life, and the legal protection of the population. It needs more than a revolution to implement the change; it needs revamped tools and it needs to build a robust attitude, a political allegiance for immediate decisions and sustainable reforms - politically agreed, financially sustained and markedly implemented.

An intelligent vision for smart times still remains vital: a performing business based on interactive analysis developed using intelligent tools of simulations are expected to pursue the universal health coverage. During the last two decades, the nature of the diseases changed towards more complex and with new conditions emerging; their incidence within a growing global population increased in such a way that what was unknown or rare once it is now recognized in high need of a targeted care and innovative treatments.

The advances are generally considered highly scientific, from various theoretical and applicative points of view: medical - as discoveries, treatments and therapies, applied care and organization, logistical structures, resources managing. Recently, at European level, more networks have been virtually created, comprising 900 highly specialized healthcare units located in 313 hospitals from 25 countries and involving health providers and high specialists to tackle the complexity of the rare diseases, to harness the intermediate and final results obtained and to apply, at a more general dimension, the specific results and special treatments based on a highly concentrated knowledge and resources. The main purpose resides in identify the ways to ameliorate the evaluation and diagnosis tracks to apply better and higher qualitative care according to measurable effects for both patients and the curing system.

The present interest in the potential of translational medicine to find the right drug for the right patient requires also the integration of several activities. These include: the search for biomarkers not only helps selecting the most specific compounds at a preclinical stage, but also serves predicting, stratifying and monitoring patients (subgroups) who will experience the requisite efficacy of the compound and an acceptable level of adverse events. The inherent sense of urgency, associated with the development stage, is driven by the competitive environment in which time to market with a differentiated product is an important determinant of success. Thus, the creation of special ware teams for individual efforts and for 


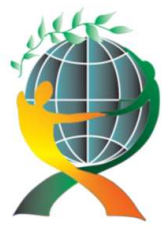

\author{
(online) $=$ ISSN $2285-3642$ \\ ISSN-L = $2285-3642$ \\ Journal of Economic Development, Environment and People \\ Volume 8, Issue 2, 2019 \\ URL: $\underline{\text { http://jedep.spiruharet.ro }}$ \\ e-mail: office jedep@spiruharet.ro
}

therapeutic franchises, which are called by development and commercial leaders, is more likely to foster the entrepreneurial behaviours identified within, such as ownership, outcome focus, passion and conviction, and the ability to recruit the best people. During the research stage, entrepreneurial behaviours are, often, compromised, by several characteristics that let in: a) increasing size and complexity of any research groups; b) larger portfolios and a focus on increasing the number of 'shots on goal'; c) insistency of focused middle managers on timelines and portfolios, instead of science, technology and leveraging external knowledge; d) influence on the business side of procurement department (too early in the process); e) evolving science and technology impact on organizational complexity; f) possibility of alignment between R\&D heads and European Commission findings, decisions and recommendations.

The fundamental objective of the research as shown ex-ante in this prolepsis remains cantered on the study of needs, expertise, resources and limitations of the different actors (pharmaceutical industry, hospitals, patient associations, regulatory bodies in the health \& medical care sector, academia), with the aim "to identify and design a sustainable innovative model of leadership and management" (Mihoreanu et al, 2013) that may act at the European level to "ameliorating the feedback towards the today patients' needs" (Mihoreanu et al, 2013). It emphasizes the need to expertise assets and limitations of different actors playing more or less important roles in the health industry and market: hospitals, clinics, diseases' and patients' associations, medical devices and pharmaceuticals corporate, regulatory bodies in the executive authorities and medical central and local administration, and offer an innovative and integrative model of leading and administrating the medical and health resources so that it will better answer the needs of today's patients.

The arguments for this demarche innate in the intricate role played by the medical, health and care sectors for all nations and the entire society at once, no matter the character of the activities: economic, social, political ones. The major job relies in taking out conspicuous errors from the trial-and-error process of drug discovery and management, so that the same level of expertise or resources that big companies have under their administration is put at a general disposal onto large models, portals, or platforms. Thus the model proposed here will insert a "flexible bridge circuit" (Bessant, 2015) over the clinical needs to the scientific discoveries from the public domain or industry within a new generation of Societal Integrative Partnering as the first step to build a new paradigm of total active satisfaction based on self-acceptance, capitalized returned added value and societal commitment. The technological configurations will induce an exponential impact if the assessment is condensed from social, economic, financial and societal points of view. Above all, the resources used in spatial and temporal manner could also be evaluated based on a theoretical conceptual framework, gathering the Compendium of Approaches for Impact Assessment of ICT-for-Development Projects (ICT4D) as Heeks and Molla (2009) or Gigler (2011) mention in their studies with regard at the "perspectives of using the evaluation framework" based on the capability approaches and on informational capabilities. Therefore, the multidisciplinary approach stays, compulsory on, at the borderline between different diseases, adequate pharmacology, entrepreneurial methods implemented, managerial theories and practices and ITC methods all covered in a new system of social education and societal benefit having multiple effects on the quality of life. Under such a frame, the wealth will not be considered as an issue, but the distribution of health is! Hence it will become reality the initial intention to dismantle the idea of going to the doctor for the last living chance and cure and transubstantiate the visit to the doctor into a perpetual form of awakened educational activity instead of a painful chore. This will show 


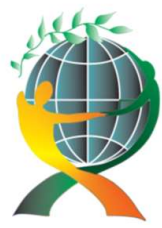

\author{
(online) $=$ ISSN $2285-3642$ \\ ISSN-L = 2285 - 3642 \\ Journal of Economic Development, Environment and People \\ Volume 8, Issue 2, 2019 \\ URL: http://jedep.spiruharet.ro \\ e-mail: office jedep@spiruharet.ro
}

the path forward to both in science and in medical services providing. The new roadmap will go farther to show more efficient sides of health managerial administration; it will nest the synergistic relation between patient - medical staff - health bodies, inside the general practitioner's environment, and will help transforming it into an educational, social and cultural landmark legitimating gain of time and money on all sides. From the model cantered on treating a disease towards a patient-cantered and later on towards the team-based model transformed these days into the patients-centric model, a new approach is presented here, the P-GP centric, into a partnering performance-based activity, integrating the terzet to profit into the institution named Society (for patient, specialist and society as a whole institutional aggregated body). This way, the innovative process will translate through science into new commercial drugs, more accurate recommendations and adequate policies to sustain and implement a sustainable model which will add real value to the society by improving patients' health and most importantly by enriching the quality of their lives. The design and articulation of public policy working for the benefit of each individual will build the path toward prosperity and harmony between society and environment and will frame the collective gains into a new paradigm. Then the Hippocrates' Oath will be heartedly, plenary and richly fulfilled.

\title{
References
}

[1]. Bergdahl, Mats, Manfred Ehling, Eva Elvers, Erika Foldesi, Thomas Korner, Andrea Kron, Peter Lohauss, Komelia Mag,Vera Morais, Anja Nimergut, Hans Vigo Saebo, Ulrike Timm and Maria Joao Zilhao, (2005), Handbook on Data Quality Assessment Methods and Tools, Manfred Ehling \& Thomas Korner (ed.), European Commission Eurostat.

[2]. Benisheva-Dimitrova Tatyana, Brborović Ognjen, Donev Doncho, Dyakova Mariana, Džakula Aleksandar, Eržen Ivan, Farkaš-Lainščak Jerneja, Fisk Malcolm, Folmer Herman R., Galan Adriana, Georgieva Lidia, Grujić Vera, Hristov Nikolay, Jakšić Želimir, Karadžinska-Bislimovska Jovanka, Karaslavova Emilia, Kirilov Kiril, Košnik Mitja, Kovačić Luka, Krajc Mateja, Lunder Urška, Martinov Cvejin Mirjana, Mijakoski Dragan, Milevska-Kostova Neda, Minov Jordan, Možina Miran, Pavlova Jasmine, Premik Marjan, Risteska-Kuc Snežana, Rudel Drago, Salchev Petko, Santrić-Miličević Milena, Scîntee Silvia Gabriela, Shipkovenska Elena, Sidjimova Dobriana, Stambolović Vuk, Stikova Elisaveta, Stoleski Sašo, Sušteršič Olga, Šogorić Selma, Švab Igor, Švab Vesna, Trendafilova Petya, Vodenicharov Tzekomir, Vončina Luka, Vukušić Rukavina Tea, Wenzel Helmut, Zaletel Marija \& Zaletel-Kragelj Lijana, (2008), "Forum For Public Health in South Eastern Europe Programmes for Training and Research" in Doris Bardehle, Luka Kovačić, Ulrich Laaser \& Oliver Razum - ed.,(2008), Public Health Management in Health Care practice A Handbook for Teachers, Researchers and Health Professionals, Kovačić Luka, Zaletel-Kragelj Lijana MetaNET \& PH-SEE Project Coordinators, Publisher: Hans Jacobs Publishing Company, Medicinska Naklada, http://dnb.ddb.de abrufbar.

[3]. Bessant, John, and Joe, Tidd, (2015), Innovation and Entrepreneurship, $3^{\text {rd }}$ Eds, John Wiley \& Sons, ISBN: 978-1118-99309-5.

[4]. Björn-Sören Gigler, (2011), Informational capabilities-the missing link for the impact of ICT on development, ETransform Knowledge Platform, Working Paper, Series 1, The World Bank, https://openknowledge.worldbank.org/bitstream/handle/10986/19011/882360NWP0Box30seriesOno10March2 011.pdf?sequence=1\&isAllowed=y

Currie, Janet, (2009), Healthy, Wealthy, and Wise: Socioeconomic Status, Poor Health in Childhood, and Human Capital Development, Journal of Economic Literature, 47, pp: 87-122. 


\author{
(online) $=$ ISSN $2285-3642$ \\ ISSN-L = $2285-3642$ \\ Journal of Economic Development, Environment and People \\ Volume 8, Issue 2, 2019 \\ URL: http://jedep.spiruharet.ro \\ e-mail: office jedep@spiruharet.ro
}

[5]. Cutler, David M., Adriana Lleras-Muney and Tom Vogl, (2012), "Socioeconomic Status and Health: Dimensions and Mechanisms", in Sherry Glied \& Peter C. Smith - ed., (2012), The Oxford Handbook of Health Economics, NY/Oxford Univ. Press.

[6]. Dobrow, Marc J., (2004), Evidence-based health policy: context and utilization, Social Sciences \& Medicine, Vol. 58(1), Jan., pp: 207-217, Elsevier.

[7]. Douglas, Angela E., (2010), The Symbiotic Habit, Princeton University Press, USA.

[8]. Douglas, Frank L., (2012), Innovation and value-driven engineering, editorial, Nature Reviews Drug Discovery, 11, 335, (May), doi: 10.1038/nrd3725, pp: 333-419.

[9]. Drysdale, Carla, (2017), World Economic Situation and Prospects 2017, United Nations Department of Economic and Social Affairs, NY, https://www.un.org/development/desa/dpad/wpcontent/uploads/sites/45/publication/2017wesp_full_en.pdf.[1]Albert-László Barabási, Mark Newman, \& Duncan J. Watts (ed.), (2006), The Structure and Dynamics of Networks, Princeton Univ. Press, Princeton and Oxford.

[10]. Fletcher, Harold D., and Darlene Brannigan-Smith, (2004), Managing for value: Developing a performance measurement system integrating economic value added and the balanced scorecard in strategic planning, Journal of Business Strategies, Vol. 21(1), (spring), Huntsville, pp:1-17.

[11]. Hauser, John, Gerard J. Tellis and Abbie Griffin, (2006), Research on Innovation: A Review and Agenda for "Marketing Science" Marketing Science, Vol. 25, No. 6, 25th Sp. Issue, (Nov.-Dec.), pp: 687-717, INFORMS.

[12]. Heeks, R. and A. Molla, A. (2009), Impact Assessment of ICT-for-Development Projects: A Compendium of Approaches, (IDPM Development Informatics Working Papers; No. 36), Manchester.

[13]. Kalinichenko Olena, Amado Carla A. F. \& Sérgio P. Santos, (2013), Performance Assessment in Primary Health Care: A Systematic Literature Review, University of Algarve, EFAGE-UE Working Paper, March, https://www.coursehero.com/file/16503455/2013-03/.

Lancaster, Jeanette and Marcia, Stanhope, (2011), Public Health Nursing Pageburst on Kno Retail Access Code: Population-Centered Health Care in the Community, $8^{\text {th }}$ eds., Elsevier Science Health Science Division, eBook ISBN: 9780323294096. The complete definition dares since 2001 in the following shape: "Health care delivery system refers to the totality of resources that a population or society distributes in the organization and delivery of health services. It also includes all personal and public services performed by individuals or institutions for the purpose of maintaining or restoring health. It implies the organization of the people, institution and resources to deliver health care services according to different demands - by demographic aims and health directions".

[14]. McKenzie Brian and Mukesh Sud, (2009), Prolegomena to a new econological perspective in entrepreneurship, Academy of Entrepreneurship Journal, Vol.15, Issue 1/2, pp: 43-60, Arden.

[15]. Monkerud Lars C and Ytterhus Bjarne, (2013), Adoption of environmental management systems and standards in Norwegian education and nursing, Baltic Journal of Management, Vol. 8, Issue 2, pp: 124-141, https://doi.org/10.1108/17465261311309984.

Murray C.J.L. and A.D. Lopez, (1996b), The global burden of a Disease: a comprehensive assessment of mortality and disability from diseases, injuries, and risk factors in 1990 and projected to 2020: summary.

[16]. World Health Organization, Geneva.

[17]. Murray C.J.L. and AD Lopez, (1996a), Evidence-based health policy: Lessons from the Global Burden of Disease Study, Science, 274 (5288), pp: 740-743. 


\author{
(online) $=$ ISSN $2285-3642$ \\ ISSN-L = $2285-3642$ \\ Journal of Economic Development, Environment and People \\ Volume 8, Issue 2, 2019 \\ URL: http://jedep.spiruharet.ro \\ e-mail: office jedep@spiruharet.ro
}

[18]. OECD Directorate for Science, Technology and Innovation, Innovation in Science, Technology and Industry, (2005), Oslo Manual: Guidelines for Collecting and Interpreting Innovation Data, $3^{\text {rd }}$ eds., pp: 13-18, www.oecd.org/sti/oslomanual.

[19]. Pässilä Anne, Tuija Oikarinen, Satu Parjanen,Vesa Harmaakorpi,(2013),Interpretative dimension of user-driven service innovation Baltic Journal of Management, Publication ID: 28348

[20]. Smith, James P, (1999), Healthy Bodies and Thick Wallets: The Dual Relation between Health and Economic Status, Journal of Economic Perspectives, 13, pp: 145-166.

[21]. Vasile, Adrian, Larisa Mihoreanu and A. Bondrea, (2013), "An Insight into the Rationality of Economic Entities: Emerging from Crises with New Approaches to Social Sciences", in D.Vrontis, Y.Weber, E.Tsoukatos, (ed.), Confronting Contemporary Business Challenges through Management Innovation $6^{\text {th }}$ Annual EuroMed Academy of Business Conference, EuroMed Press, pp: 2853-2858, ISBN: 978-9963-711-16-1, http://emrbi.org/wpcontent/uploads/2014/09/euromed-6-2013.pdf.

Viciu,Tania, Larisa Mihoreanu and Laura Goran, (2013), "The contemporary Homo-economicus defining wellbeing at the Crossroads of Economic Growth and Business Ethics" in D.Vrontis, Y.Weber, E.Tsoukatos, (ed.), Confronting Contemporary Business Challenges through Management Innovation $6^{\text {th }}$ Annual EuroMed Academy of Business Conference, Euro MedPress, pp: 2860-2865, ISBN: 978-9963-711-16-1, ISI Proceedings, http://emrbi.org/wpcontent/uploads/2014/09/euromed-6-2013.pdf.

Wolfe, Richard A., (1994), Organizational Innovation: Review, Critique and Suggested Research Directions, Journal of Management Studies, Vol., Issue 3, May, pp: 405-431, https://doi.org/10.1111/j.14676486.1994.tb00624.x.

World Health Organization - WHO, (2013), Research for Universal Health Coverage: 2013 World Health Report, ISBN: 9789241564595.

[22]. World Health Organization, (2007), Everybody business: strengthening health systems to improve health outcomes: WHO's framework for action, ISBN 9789241596077.

[23]. Young, Pauline V., (1960), Scientific Social Surveys and Research, $3^{\text {rd }}$ eds., NY, Prentice-Hall, p: 30. 